\title{
Natropalermoite, $\mathrm{Na}_{2} \mathrm{SrAl}_{4}\left(\mathrm{PO}_{4}\right)_{4}(\mathrm{OH})_{4}$, a new mineral isostructural with palermoite, from the Palermo No. 1 mine, Groton, New Hampshire, USA
}

\author{
Benjamin N. Schumer ${ }^{*}$, Hexiong Yang and Robert T. Downs \\ Department of Geosciences, University of Arizona, 1040 E 4th Street, Tucson, AZ 85721-0077, USA
}

[Received 6 October 2015; Accepted 28 June 2016; Associate Editor: Ian Graham]

\section{ABSTRACT}

Natropalermoite, ideally $\mathrm{Na}_{2} \mathrm{SrAl}_{4}\left(\mathrm{PO}_{4}\right)_{4}(\mathrm{OH})_{4}$, the Na-analogue of palermoite, is a new mineral from the Palermo No. 1 mine, Groton, New Hampshire, USA. Associated minerals are palermoite, eosphorite and quartz. Natropalermoite crystals are prismatic with striations parallel to the direction of elongation (the $a$ axis) up to $200 \mu \mathrm{m} \times 50 \mu \mathrm{m} \times 45 \mu \mathrm{m}$ in size. The mineral is colourless, transparent with a white streak and vitreous lustre and is visually indistinguishable from palermoite. It is brittle with subconchoidal fracture and has a Mohs hardness of 5.5. Cleavage is perfect on $\{001\}$, fair on $\{100\}$ and no parting was observed. The calculated density is $3.502 \mathrm{~g} \mathrm{~cm}^{-3}$. Natropalermoite is biaxial $(-), \alpha=1.624(1), \beta=1.641(1), \gamma=1.643(1)$ $(589 \mathrm{~nm}), 2 \mathrm{~V}_{\text {meas }}=43(4)^{\circ}, 2 \mathrm{~V}_{\text {calc }}=38^{\circ}$. An electron microprobe analysis yielded an empirical formula (based on $20 \mathrm{O}$ apfu) of $\left(\mathrm{Na}_{1.69} \mathrm{Li}_{0.31}\right)_{\Sigma 2.00}\left(\mathrm{Sr}_{0.95} \mathrm{Mg}_{0.04} \mathrm{Ca}_{0.02} \mathrm{Ba}_{0.01}\right)_{\Sigma 1.02}\left(\mathrm{Al}_{3.82} \mathrm{Mn}_{0.03} \mathrm{Fe}_{0.03}\right)_{\Sigma 3.88}\left(\mathrm{P}_{1.01} \mathrm{O}_{4}\right)_{4}(\mathrm{OH})_{4}$.

Natropalermoite is orthorhombic, space group Imcb, $a=11.4849(6), b=16.2490(7), c=7.2927(4) \AA$, $V=1360.95(17) \AA^{3}, Z=4$. Natropalermoite is isotypic with palermoite, but substitution of the larger $\mathrm{Na}$ for $\mathrm{Li}$ results in substantial increase of the $b$ cell parameter. Four of the seven $\mathrm{Na}-\mathrm{O}$ distances are longer than their equivalents in palermoite, resulting in a more regular 7-fold coordination polyhedron about Na. The eight strongest peaks in the calculated X-ray powder diffraction are $\left[d_{\text {calc }}(\AA), I_{\text {rel }} \%,(h k l)\right]:[3.128,100,(321)]$, $[4.907,68,(121)],[3.327,48,(022)],[4.689,45,(220)],[3.078,45,(202)],[2.453,38,(242)],[2.636,35$, (411)], [2.174, 35, (422)].

KEYWoRDs: natropalermoite, new mineral, phosphate, Palermo No. 1 mine, pegmatite.

\section{Introduction}

A new mineral species, natropalermoite, ideally $\mathrm{Na}_{2} \mathrm{SrAl}_{4}\left(\mathrm{PO}_{4}\right)_{4}(\mathrm{OH})_{4}$, was found in a sample from the Palermo No. 1 mine, Groton, New Hampshire. The name reflects the presence of sodium (natrium) and the structural isomorphism to palermoite. The new mineral and its name have been approved by the Commission on New Minerals, Nomenclature and Classification (CNMNC) of the International Mineralogical Association (IMA 2013-118). The holotype sample is deposited in the collections of the Mineral Museum of the University of Arizona,

*E-mail: bschumer@email.arizona.edu https://doi.org/10.1180/minmag.2016.080.133
Tucson, Arizona, USA, catalogue number 19735, and the RRUFF Project, deposition number R130092 (http://ruff.info/R130092). This paper describes the physical and chemical properties of natropalermoite and the characterization of the structure based on single-crystal X-ray diffraction data.

\section{Sample description and experimental methods}

Occurrence, physical and chemical properties and Raman spectra

Natropalermoite was found in a sample from the Palermo No. 1 mine, Groton, Grafton County, New Hampshire, USA which exploited a complex, 


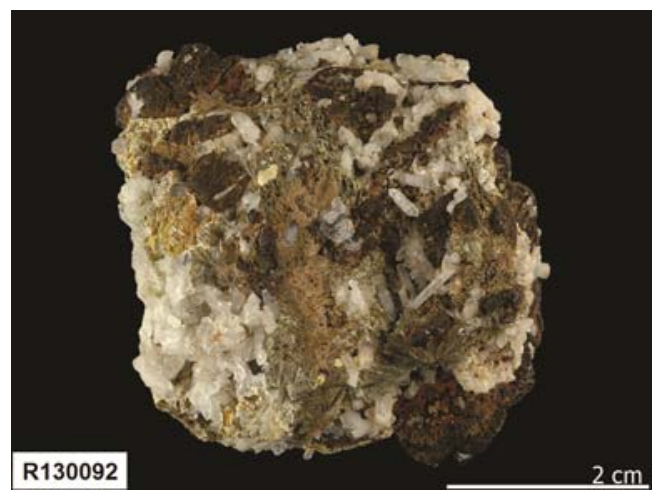

FIG. 1. The sample on which natropalermoite was found.

phosphate-bearing granite pegmatite for mica, feldspar and beryl (Cameron et al., 1954; Page and Larrabee, 1962). Associated minerals include palermoite, childrenite, lefontite, mixed iron oxides and quartz (Fig. 1). Natropalermoite is of secondary origin, formed as a result of hydrothermal alteration of primary triphylite pods in the core-margin zone of the pegmatite (Page and Larrabee, 1962; Segeler et al., 1981). Palermoite in association with natropalermoite shows cores of near end-member composition with rims richer in $\mathrm{Na}$, indicating that natropalermoite forms later than palermoite. The Palermo No. 1 mine was brought into the mineralogical spotlight by the host of secondary phosphate phases found there, and is the type locality for 12 phosphate species, not including natropalermoite: palermoite, whitlockite, goedkenite, schoonerite, bjarebyite, whitmoreite, wolfeite, xanthoxenite, foggite, samuelsonite, falsterite and nizamoffite (Kampf et al., 2013 and references therein).

Natropalermoite crystals are prismatic, up to $200 \mu \mathrm{m} \times 50 \mu \mathrm{m} \times 45 \mu \mathrm{m}$ in size, elongated and striated along the $a$ axis (Fig. 2). In transmitted light, natropalermoite is colourless and transparent, with a vitreous lustre. It is brittle, has perfect cleavage on $\{001\}$, fair on $\{100\}$ and no parting was observed. Fracture is sub-conchoidal to fibrous. Hardness was not measured but is most likely 5.5 by analogy with palermoite. Natropalermoite is nonpleochroic, biaxial (-), $\alpha=1.624(1), \beta=1.641(1)$, $\gamma=1.643(1)(589 \mathrm{~nm}), 2 \mathrm{~V}_{\text {meas }}=43(4)^{\circ}, 2 \mathrm{~V}_{\text {calc }}=38^{\circ}$, dispersion $v>r$, medium to weak. Because of the paucity of crystals, no density was measured. The calculated density is $3.502 \mathrm{~g} \mathrm{~cm}^{-3}$. Natropalermoite is insoluble in water and acetone.

The chemical composition of natropalermoite was determined using a CAMECA SX100 electron microprobe with beam conditions of $15 \mathrm{kV}, 4 \mathrm{nA}$

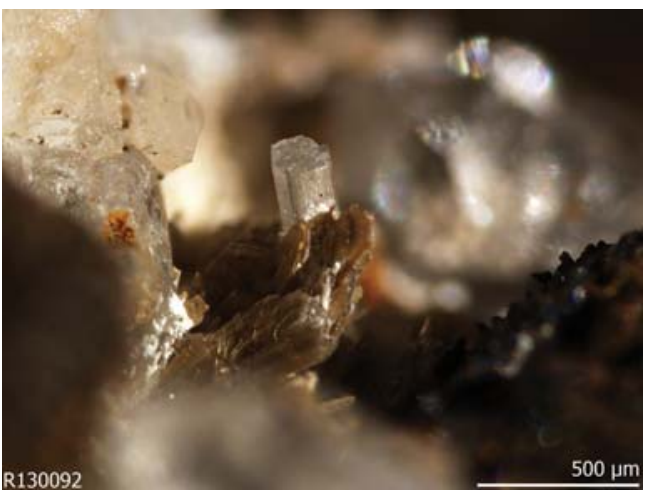

FIG. 2. Prismatic crystal of natropalermoite growing on greyish brown childrenite. Note weak striations parallel to the axis of elongation $a$. The top portion of this crystal was used for X-ray, chemistry and optical data collection.

and a beam diameter of $5 \mu \mathrm{m}$. Standards used were $\mathrm{K}$-feldspar for Al, albite for $\mathrm{Na}$, synthetic apatite for $\mathrm{Ca}$ and $\mathrm{P}$, synthetic $\mathrm{SrTiO}_{3}$ for $\mathrm{Sr}$, rhodonite for $\mathrm{Mn}$, forsterite for $\mathrm{Mg}$, fayalite for $\mathrm{Fe}$ and baryte for $\mathrm{Ba}$. The presence of $\mathrm{OH}$ was confirmed by both structural determination and Raman spectroscopic measurements (see below), and the amount of $\mathrm{OH}$ was estimated by stoichiometry from the crystalstructure refinement. Not enough material was available for the direct determination of $\mathrm{Li}_{2} \mathrm{O}$, which was estimated by stoichiometry from the crystal-structure refinement. An average of 10 spot analyses (Table 1) yielded an empirical formula of $\left(\mathrm{Na}_{1.69} \mathrm{Li}_{0.31}\right)_{\Sigma 2.00}\left(\mathrm{Sr}_{0.95} \mathrm{Mg}_{0.04} \mathrm{Ca}_{0.02} \mathrm{Ba}_{0.01}\right)_{\Sigma 1.02}$ $\left(\mathrm{Al}_{3.82} \mathrm{Mn}_{0.03} \mathrm{Fe}_{0.03}\right)_{\Sigma 3.88}\left(\mathrm{P}_{1.01} \mathrm{O}_{4}\right)_{4}(\mathrm{OH})_{4}$ based

TABLE 1. Microprobe data for natropalermoite, standard deviation in weight percent are indicated by numbers in parenthesis.

\begin{tabular}{lccc}
\hline Constituent & wt.\% & Range & Probe standard \\
\hline $\mathrm{Al}_{2} \mathrm{O}_{3}$ & $28.6(2)$ & $28.39-28.95$ & K-feldspar \\
$\mathrm{Mn}_{2} \mathrm{O}_{3}$ & $0.36(9)$ & $0.17-0.50$ & Rhodonite \\
$\mathrm{Fe}_{2} \mathrm{O}_{3}$ & $0.35(4)$ & $0.31-0.41$ & Fayalite \\
$\mathrm{Na}_{2} \mathrm{O}$ & $7.68(10)$ & $7.56-7.87$ & Albite \\
$\mathrm{Li}_{2} \mathrm{O}$ & 0.69 & & $*$ \\
$\mathrm{MgO}$ & $0.26(3)$ & $0.22-0.31$ & Forsterite \\
$\mathrm{CaO}$ & $0.16(4)$ & $0.11-0.20$ & Apatite, synthetic \\
$\mathrm{SrO}$ & $14.5(4)$ & $14.23-15.29$ & SrTiO \\
$\mathrm{BaO}$ & $0.14(4)$ & $0.10-0.21$ & Barite \\
$\mathrm{P}_{2} \mathrm{O}_{5}$ & $42.28(13)$ & $42.06-42.46$ & Apatite, synthetic \\
$\mathrm{H}_{2} \mathrm{O}$ & 5.29 & & $*$ \\
Total & 100.29 & & \\
& & & \\
\hline
\end{tabular}

*Estimated from structure refinement stoichiometry. 
TABLE 2. Summary of crystal data and refinement results for natropalermoite.

\begin{tabular}{|c|c|}
\hline & $\begin{array}{c}\text { Natropalermoite (R130092, } \\
\text { New Hampshire) }\end{array}$ \\
\hline $\begin{array}{l}\text { IMA-defined chemical } \\
\text { formula }\end{array}$ & $\mathrm{Na}_{2} \mathrm{SrAl}_{4}\left(\mathrm{PO}_{4}\right)_{4}(\mathrm{OH})_{4}$ \\
\hline $\begin{array}{l}\text { Effective structural } \\
\text { formula }\end{array}$ & $\begin{array}{c}\left(\mathrm{Na}_{1.69} \mathrm{Li}_{0.31}\right)_{\Sigma 2.00} \\
\left(\mathrm{Sr}_{0.95} \mathrm{Mg}_{0.04} \mathrm{Ca}_{0.02} \mathrm{Ba}_{0.01}\right)_{\Sigma 1.02} \\
\left(\mathrm{Al}_{3.82} \mathrm{Mn}_{0.03} \mathrm{Fe}_{0.03}\right)_{\Sigma 3.88} \\
\left(\mathrm{P}_{1.01} \mathrm{O}_{4}\right)_{4}(\mathrm{OH})_{4}\end{array}$ \\
\hline $\begin{array}{l}\text { Space group } \\
a(\AA)\end{array}$ & $\begin{array}{c}\operatorname{Imcb} \\
11.4849(6)\end{array}$ \\
\hline$b(\AA)$ & $16.2490(7)$ \\
\hline$c(\AA)$ & $7.2927(4)$ \\
\hline$V\left(\AA^{3}\right)$ & $1360.95(17)$ \\
\hline$Z$ & 4 \\
\hline$\rho_{\text {calc }}\left(\mathrm{g} \mathrm{cm}^{-3}\right)$ & 3.328 \\
\hline$\lambda(\AA)$ & 0.71073 \\
\hline$\mu\left(\mathrm{mm}^{-1}\right)$ & 4.73 \\
\hline $\begin{array}{l}2 \theta \text { range for data } \\
\text { collection }\end{array}$ & $<65.19^{\circ}$ \\
\hline $\begin{array}{l}\text { No. of reflections } \\
\text { collected }\end{array}$ & 5970 \\
\hline $\begin{array}{l}\text { No. of independent } \\
\text { reflections }\end{array}$ & 1257 \\
\hline $\begin{array}{l}\text { No. of reflections with } \\
I>2 \sigma(I)\end{array}$ & 1132 \\
\hline $\begin{array}{l}\text { No. of parameters } \\
\text { refined }\end{array}$ & 86 \\
\hline $\mathrm{R}$ (int) & 0.0271 \\
\hline $\begin{array}{l}\text { Final } R_{1}, w R_{2} \text { factors } \\
\quad[I>2 \sigma(I)]\end{array}$ & $0.0207,0.0564$ \\
\hline $\begin{array}{l}\text { Final } R_{1}, w R_{2} \text { factors } \\
\quad \text { (all data) }\end{array}$ & $0.0252,0.0564$ \\
\hline Goof & 1.034 \\
\hline
\end{tabular}

on $20 \mathrm{O}$ atoms per formula unit (apfu), which can be simplified to $\mathrm{Na}_{2} \mathrm{SrAl}_{4}\left(\mathrm{PO}_{4}\right)_{4}(\mathrm{OH})_{4}$.

The Raman spectrum of natropalermoite was collected from a randomly oriented crystal on a Thermo Almega microRaman system, using a 532-nm solid-state laser with a thermoelectric cooled CCD detector. The laser is partially polarized with $4 \mathrm{~cm}^{-1}$ resolution and a spot size of $1 \mu \mathrm{m}$.

\section{X-ray crystallography}

Due to the paucity of material, powder X-ray diffraction data of natropalermoite (Table 2) were calculated from the determined structure using the program XPOW (Downs et al., 1993).

Single-crystal X-ray diffraction data (Table 3) of natropalermoite were collected using a Bruker X8
TABLE 3. Calculated powder $\mathrm{X}$-ray diffraction data for natropalermoite.

\begin{tabular}{lllll}
\hline$I_{\text {rel }}$ & $d_{\text {calc }}$ & $h$ & $k$ & $l$ \\
\hline 33 & 6.653 & 0 & 1 & 1 \\
14 & 5.743 & 2 & 0 & 0 \\
$\mathbf{6 8}$ & $\mathbf{4 . 9 0 7}$ & $\mathbf{1}$ & $\mathbf{2}$ & $\mathbf{1}$ \\
$\mathbf{4 5}$ & $\mathbf{4 . 6 8 9}$ & $\mathbf{2}$ & $\mathbf{2}$ & $\mathbf{0}$ \\
20 & 4.347 & 2 & 1 & 1 \\
32 & 3.399 & 1 & 1 & 2 \\
$\mathbf{4 8}$ & $\mathbf{3 . 3 2 7}$ & $\mathbf{0}$ & $\mathbf{2}$ & $\mathbf{2}$ \\
$\mathbf{1 0 0}$ & $\mathbf{3 . 1 2 8}$ & $\mathbf{3}$ & $\mathbf{2}$ & $\mathbf{1}$ \\
$\mathbf{4 5}$ & $\mathbf{3 . 0 7 8}$ & $\mathbf{2}$ & $\mathbf{0}$ & $\mathbf{2}$ \\
17 & 2.968 & 0 & 5 & 1 \\
19 & 2.637 & 2 & 5 & 1 \\
$\mathbf{3 5}$ & $\mathbf{2 . 6 3 6}$ & $\mathbf{4}$ & $\mathbf{1}$ & $\mathbf{1}$ \\
21 & 2.606 & 3 & 1 & 2 \\
22 & 2.479 & 1 & 6 & 1 \\
$\mathbf{3 8}$ & $\mathbf{2 . 4 5 3}$ & $\mathbf{2}$ & $\mathbf{4}$ & $\mathbf{2}$ \\
24 & 2.396 & 4 & 3 & 1 \\
27 & 2.171 & 0 & 6 & 2 \\
$\mathbf{3 5}$ & $\mathbf{2 . 1 7 4}$ & $\mathbf{4}$ & $\mathbf{2}$ & $\mathbf{2}$ \\
17 & 2.031 & 0 & 8 & 0 \\
13 & 1.843 & 4 & 1 & 3 \\
31 & 1.663 & 0 & 4 & 4 \\
15 & 1.658 & 4 & 8 & 0 \\
15 & 1.611 & 4 & 5 & 3 \\
& & & &
\end{tabular}

Only calculated lines with $I_{\text {calc }}>12$ are included.

The strongest lines are given in bold.

APEX2 CCD diffractometer equipped with graphite-monochromatized $\mathrm{MoK \alpha}$ radiation, with frame widths of $0.5^{\circ}$ in $\omega$ and $30 \mathrm{~s}$ counting time per frame. All reflections were indexed based on an orthorhombic unit cell. The intensity data were corrected for X-ray absorption using the Bruker program SADABS. SHELX97 (Sheldrick 2008) was used for structure determination and refinement. The final crystal structure was solved and refined with space group Imcb resulting in $R_{1}=0.021$, $w R_{2}=0.0564$ for 1257 reflections with $F_{\mathrm{o}}>4 \sigma\left(F_{\mathrm{o}}\right)$. Final atom positions, occupancies and isotropic and anisotropic displacement parameters are given in Table 4, and selected bond distances are given in Table 5. For the refinement, site occupancies were refined for sites Sr and Na to account for substitution of $\mathrm{Ca}$ for $\mathrm{Sr}$ and $\mathrm{Li}$ for $\mathrm{Na}$, respectively, ignoring other trace elements. The refinement showed $0.04 \mathrm{Ca}$ apfu replacing $\mathrm{Sr}$ and $0.05 \mathrm{Li}$ apfu replacing $\mathrm{Na}$, compared to $0.02 \mathrm{Ca}$ apfu measured and $0.16 \mathrm{Li}$ apfu estimated from the microprobe analysis. 
TABLE 4. Coordinates and displacement parameters for natropalermoite. Assumed average position of $\mathrm{H} 2$ is included for completeness.

\begin{tabular}{|c|c|c|c|c|c|c|c|c|c|c|c|}
\hline Atom & $x$ & $y$ & $z$ & $U_{\text {eq }}$ & Occ. $(<1)$ & $U^{11}$ & $U^{22}$ & $U^{33}$ & $U^{12}$ & $U^{13}$ & $U^{23}$ \\
\hline $\mathrm{Sr}$ & 0.25 & 0.5 & 0.5 & $0.01173(10)$ & $0.962(4)$ & $0.01685(17)$ & $0.01113(15)$ & $0.00722(14)$ & 0 & 0 & 0 \\
\hline $\mathrm{Ca}$ & 0.25 & 0.5 & 0.5 & $0.01173(10)$ & $0.038(4)$ & $0.01685(17)$ & $0.01113(15)$ & $0.00722(14)$ & 0 & 0 & 0 \\
\hline $\mathrm{Li}$ & 0.5 & $0.28990(6)$ & $0.24295(14)$ & 0.0185 & $0.047(6)$ & $0.0322(7)$ & $0.0071(5)$ & $0.0162(5)$ & 0 & 0 & $0.0013(3)$ \\
\hline $\mathrm{Na}$ & 0.5 & $0.28990(6)$ & $0.24295(14)$ & $0.0185(3)$ & $0.953(6)$ & $0.0322(7)$ & $0.0071(5)$ & $0.0162(5)$ & 0 & 0 & $0.0013(3)$ \\
\hline $\mathrm{P} 1$ & 0.25 & $0.28936(3)$ & 0.5 & $0.00567(12)$ & & $0.0051(2)$ & 0.0057 (2) & $0.0062(2)$ & 0 & 0.00005 (16) & 0 \\
\hline $\mathrm{P} 2$ & 0 & 0.46228 & $0.76986(7)$ & $0.00647(12)$ & & $0.0077(2)$ & $0.0063(2)$ & $0.0054(2)$ & 0 & 0 & $-0.00014(16)$ \\
\hline $\mathrm{Al}$ & 0.13198 & $0.37236(3)$ & $0.13801(6)$ & 0.00707 (11) & & $0.0054(2)$ & $0.0074(2)$ & $0.0084(2)$ & $-0.00058(14)$ & $0.00156(15)$ & $-0.00068(14)$ \\
\hline $\mathrm{O} 1$ & $0.14274(9)$ & $0.26571(7)$ & $0.03332(14)$ & $0.0092(2)$ & & $0.0069(5)$ & $0.0080(5)$ & $0.0128(5)$ & 0.0010 & 0.0001 (4) & $-0.0018(4)$ \\
\hline $\mathrm{O} 2$ & $0.22871(9)$ & $0.34742(7)$ & $0.33754(14)$ & $0.0094(2)$ & & $0.0096(5)$ & $0.0106(5)$ & $0.0080(5)$ & $-0.0011(4)$ & $-0.0012(4)$ & 0.0028 (4) \\
\hline $\mathrm{O} 3$ & 0 & $0.40980(10)$ & 0.6008 & $0.0141(3)$ & & $0.0210(8)$ & $0.0141(7)$ & $0.0073(7)$ & 0 & 0 & $-0.0034(5)$ \\
\hline $\mathrm{O} 4$ & 0 & $0.40464(9)$ & $0.9440(2)$ & $0.0101(3)$ & & $0.0156(8)$ & $0.0078(7)$ & $0.0070(6)$ & 0 & 0 & $0.0014(5)$ \\
\hline O5 & $0.11018(9)$ & $0.48323(7)$ & $0.22553(14)$ & $0.0091(2)$ & & 0.0067 (5) & 0.0093 (4) & $0.0111(5)$ & $0.0000(3)$ & $0.0000(4)$ & $-0.0001(4)$ \\
\hline $\mathrm{O}-\mathrm{H} 1$ & 0 & $0.34231(9)$ & $0.2617(2)$ & $0.0074(3)$ & & $0.0066(6)$ & $0.0096(6)$ & $0.0059(6)$ & 0 & 0 & $0.0002(5)$ \\
\hline $\mathrm{O}-\mathrm{H} 2$ & 0.25 & $0.41142(11)$ & 0 & $0.0124(3)$ & & $0.0149(8)$ & 0.0089 (7) & $0.0136(7)$ & 0 & $0.0085(6)$ & 0 \\
\hline $\mathrm{H} 1$ & 0 & $0.359(3)$ & $0.376(5)$ & $0.037(10)$ & & & & & & & \\
\hline $\mathrm{H} 2 *$ & 0.25 & 0.47 & 0 & & & & & & & & \\
\hline
\end{tabular}

*Assumed average position of $\mathrm{H} 2$. 
TABLE 5. Selected bond distances $(\AA)$ in natropalermoite.

\begin{tabular}{llllll}
\hline $\mathrm{Sr}$ & $-\mathrm{O} 5 \times 4$ & $2.5806(10)$ & $\mathrm{P} 1$ & $-\mathrm{O} 2 \times 2$ & $1.5341(11)$ \\
& $-\mathrm{O} 2 \times 4$ & $2.7587(11)$ & & $-\mathrm{O} 1 \times 2$ & $1.5419(11)$ \\
& Avg. & 2.6697 & & Avg. & 1.5380 \\
& & & & \\
$\mathrm{Na} \quad-\mathrm{OH} 1$ & $2.1487(16)$ & $\mathrm{P} 2$ & $-\mathrm{O} 3$ & $1.4990(16)$ \\
& $-\mathrm{O} 3$ & $2.2568(19)$ & & $-\mathrm{O} 5 \times 2$ & $1.5447(11)$ \\
& $-\mathrm{O} 4$ & $2.3095(18)$ & & $-\mathrm{O} 4$ & $1.5778(16)$ \\
& $-\mathrm{O} 1 \times 2$ & $2.4831(13)$ & & Avg. & 1.5427 \\
& $-\mathrm{O} 1 \times 2$ & $2.6270(13)$ & & & \\
& Avg. & 2.4248 & & \\
& & & & \\
$\mathrm{Al}$ & $-\mathrm{OH} 2$ & $1.8036(8)$ & & & \\
& $-\mathrm{OH} 1$ & $1.8303(9)$ & & & \\
& $-\mathrm{O} 2$ & $1.8751(11)$ & & & \\
& $-\mathrm{O} 1$ & $1.8977(12)$ & & & \\
& $-\mathrm{O} 5$ & $1.9277(12)$ & & & \\
& $-\mathrm{O} 4$ & $2.1390(12)$ & & & \\
& Avg. & 1.9122 & & \\
& & & & & \\
& & & & \\
\end{tabular}

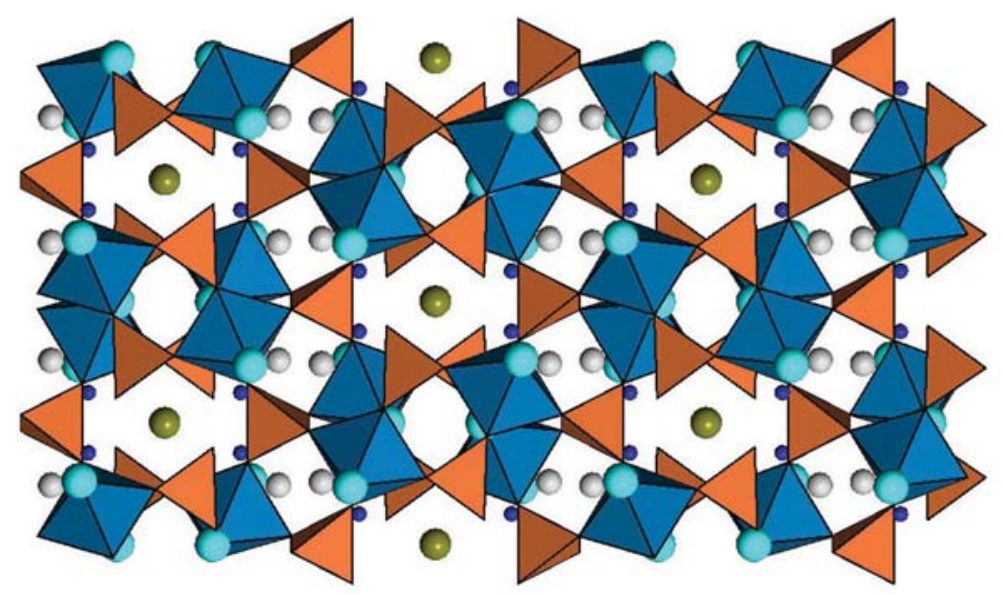

Fig. 3. The crystal structure of natropalermoite, viewed along [100]. Grey, golden, sky blue and blue spheres represent $\mathrm{Na}, \mathrm{Sr}, \mathrm{OH}$ and $\mathrm{H}$ respectively. Orange tetrahedra are $\mathrm{PO}_{4}$ groups and cerulean octahedra are $\mathrm{AlO}_{6}$ groups.

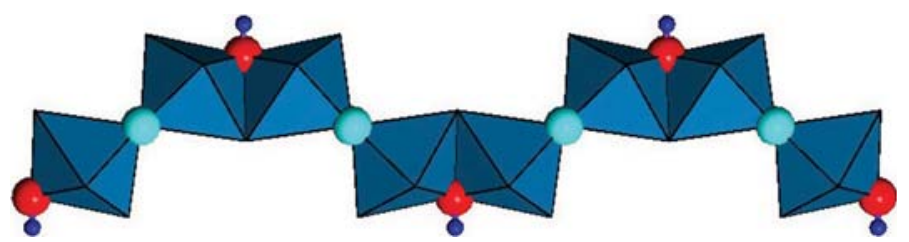

Fig. 4. The zigzag chain of $\mathrm{Al}_{2} \mathrm{O}_{7}(\mathrm{OH})_{3}$ dimers, looking down [010], [100] is horizontal. Cerulean octahedra are $\mathrm{AlO}_{6}$ octahedra, red spheres represent $\mathrm{O}-\mathrm{H} 1$, while light-blue spheres represent the $\mathrm{OH} 2$ group. 


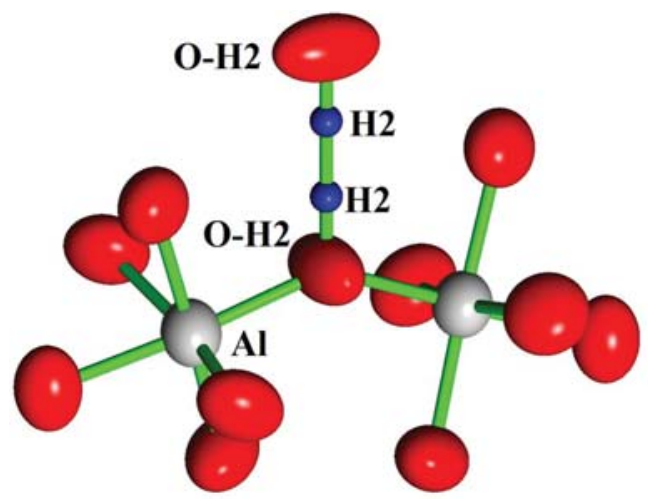

FIG. 5. The Al dimer, with each atom shown as an ellipsoid of $99.999 \%$ probability. In particular note the elongated $\mathrm{O}-\mathrm{H} 2$ ellipsoid indicating significant libration in the direction perpendicular to the $\mathrm{Al}-\mathrm{O}-\mathrm{Al}$ plane. The $\mathrm{H} 2$ position is the average likely position that must also have significant motion related to riding on $\mathrm{O}-\mathrm{H} 2$ and repulsion from its neighbouring $\mathrm{H} 2$ atom.

\section{Discussion}

\section{Crystal structure}

Natropalermoite, $\mathrm{Na}_{2} \mathrm{SrAl}_{4}\left(\mathrm{PO}_{4}\right)_{4}(\mathrm{OH})_{4}$, is isostructural with palermoite, $\mathrm{Li}_{2} \mathrm{SrAl}_{4}\left(\mathrm{PO}_{4}\right)_{4}(\mathrm{OH})_{4}$, the structure of which was described by Moore and
Araki (1975). The natropalermoite structure contains five non-H cation sites: one each for $\mathrm{Sr}^{2+}, \mathrm{Na}^{+}$, $\mathrm{Al}^{3+}$, and two for $\mathrm{P}^{5+}$ (P1 and P2), and two nonequivalent $\mathrm{H}$ atoms. The crystal structure of natropalermoite is shown in Fig. 3. Two $\mathrm{AlO}_{4}(\mathrm{OH})_{2}$ octahedra form edge-sharing $\mathrm{Al}_{2} \mathrm{O}_{7}(\mathrm{OH})_{3}$ dimers. These dimers are cornerlinked to one another through $(\mathrm{OH}) 2$, forming infinite zigzag chains along [100] (Fig. 4). The chains themselves are hexagonal close-packed, accounting for the pseudohexagonal prismatic morphology of the crystals. The zigzag chains are interconnected by $\mathrm{PO}_{4}$ groups, which share all four $\mathrm{O}$ atoms with Al. Sodium and $\mathrm{Sr}$ atoms are 7- and 8-coordinated, respectively, and are located in two distinct types of channels parallel to [100]. When viewed along [100], the $\mathrm{Na}$ atoms are staggered within their respective channels, forming a 'doublestack' arrangement, while the Sr atoms are 'singlefile' (Fig. 3). Most remarkably, due to the substitution of $\mathrm{Na}$ for $\mathrm{Li}$, the unit cell $b$ dimension of natropalermoite is significantly longer than that of palermoite: the larger $\mathrm{Na}$ atoms increase the width of their accommodating channels in the [010] direction, lengthening the overall $b$ dimension of the unit cell. As the channels widen along [010], the angle between the two octahedra in the $\mathrm{Al}_{2} \mathrm{O}_{7}(\mathrm{OH})_{3}$ dimer narrows, resulting in the

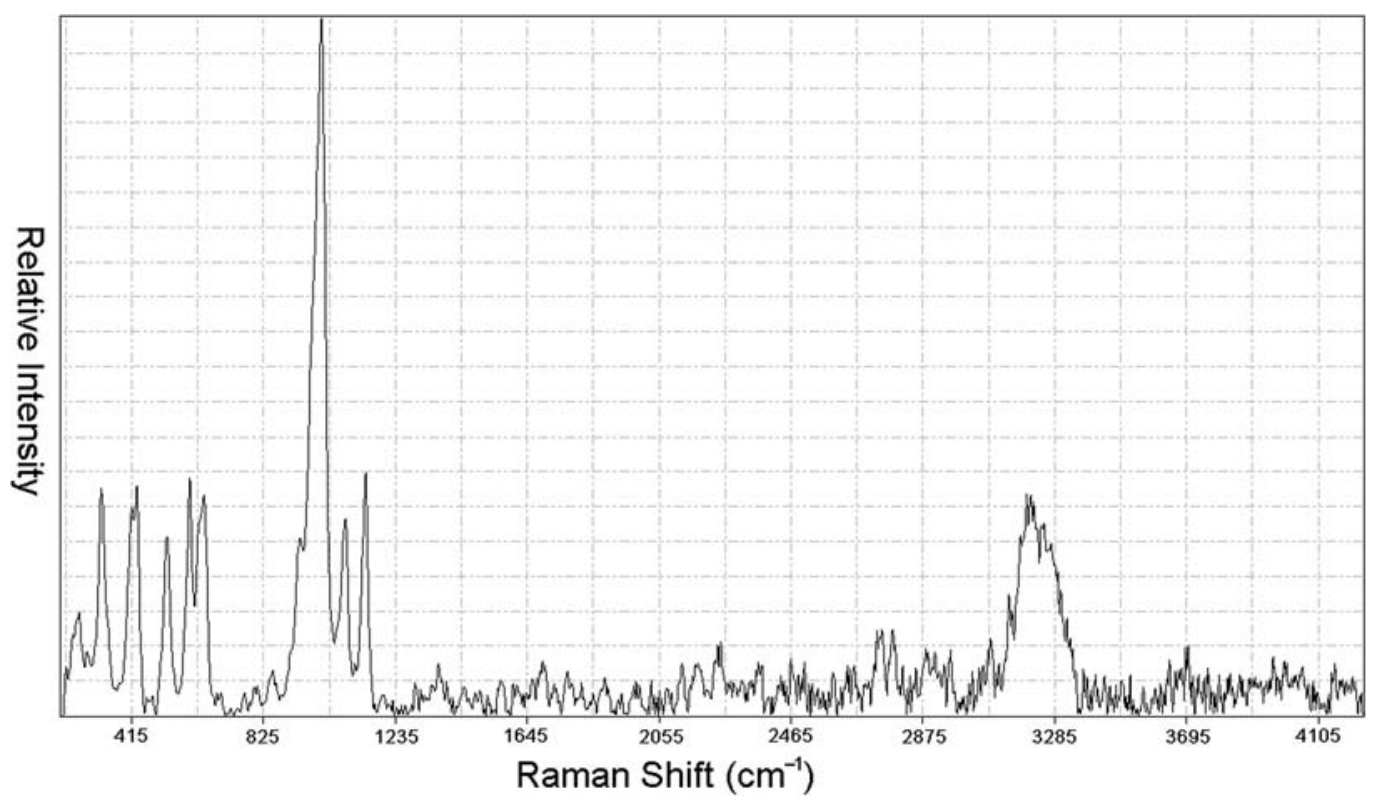

FIG. 6. Raman spectrum of natropalermoite, showing acoustic and optical modes (left) and a broad band at $3215 \mathrm{~cm}^{-1}$ attributed to $\mathrm{O}-\mathrm{H}$ stretching. 


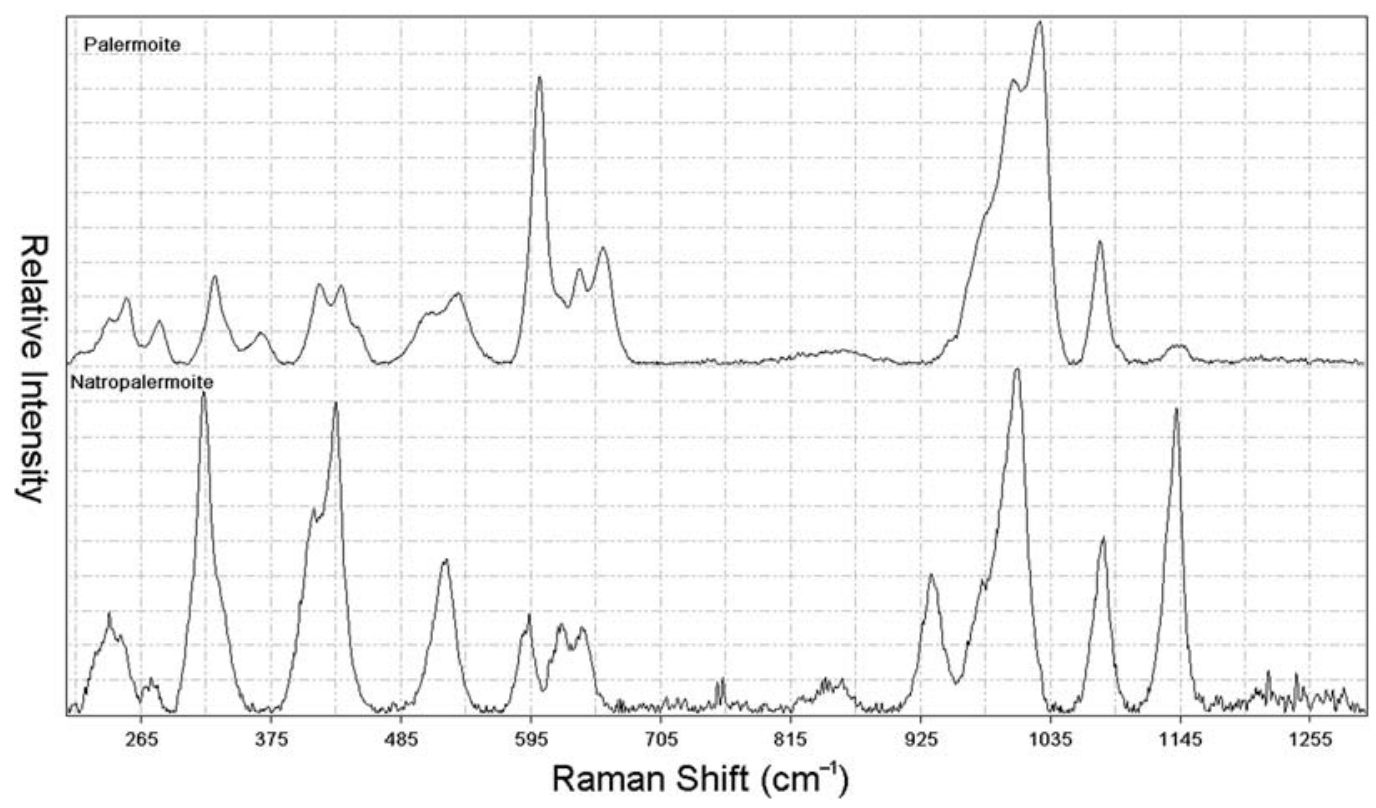

FIG. 7. The Raman spectrum of natropalermoite (lower) compared with that of palermoite (upper).

shortening of the $a=11.4849(6)$ and $c=7.2927(4) \AA$ dimensions of natropalermoite versus those of palermoite: $a=11.577(1)$ and $c=7.3276(7) \AA$. The $b$ cell edge is the distinguishing crystallographic parameter which can be used to differentiate natropalermoite from palermoite.

The position of the $\mathrm{H} 1$ atom was determined during the structure refinement, indicating the presence of $\mathrm{OH}$ in natropalermoite. The $\mathrm{H} 1$ atom is bonded to $\mathrm{O}-\mathrm{H} 1$, which is one of the two atoms in the shared edge of the $\mathrm{Al}_{2} \mathrm{O}_{7}(\mathrm{OH})_{3}$ dimer. Coordinates for the second $\mathrm{H} 2$ atom could not be refined, however valence considerations point to $\mathrm{O}-\mathrm{H} 2$, the bridging atom linking dimers. The average position of atom $\mathrm{H} 2$ was assumed to be $x=0.25, y=\sim 0.47, \mathrm{z}$ $=0$. This position must represent an average because $\mathrm{O}-\mathrm{H} 2$, which links two $\mathrm{AlO}_{6}$ octahedra, undergoes considerable libration, demonstrated by its elongated displacement ellipsoid, oriented perpendicular to the Al-O-Al plane (Fig. 5), making it extremely difficult to observed the electron density associated with the $\mathrm{H} 2$ atom.

Natropalermoite is structurally related to carminite, $\mathrm{PbFe}_{2}^{3+}\left(\mathrm{AsO}_{4}\right)_{2}(\mathrm{OH})_{2}$. The structures of natropalermoite and carminite contain the same zig-zag chain of $M_{2} \mathrm{O}_{7}(\mathrm{OH})_{3}$ edge-sharing dimers linked by $\mathrm{OH} 2$, with individual chains interconnected by $\mathrm{TO}_{4}$ tetrahedra (Moore and Araki, 1975). The difference between natropalermoite and carminite lies in accommodation of $\mathrm{Na}$ in natropalermoite. Two equivalent $\mathrm{Na}$ atoms of sitesymmetry $m$ in natropalermoite take the place of the single $\mathrm{Pb} 2$ atom of site-symmetry $2 / m$ in carminite. For a detailed comparison between palermoite and carminite, see Moore and Araki (1975).

\section{Raman spectroscopy}

The Raman spectrum of a natropalermoite crystal in unknown orientation is shown in Fig. 6. The band at $3215 \mathrm{~cm}^{-1}$ can be attributed to $\mathrm{O}-\mathrm{H}$ stretching vibrations. Bands between $1142 \mathrm{~cm}^{-1}$ and $524 \mathrm{~cm}^{-1}$ are interpreted as $\mathrm{P}-\mathrm{O}$ stretching and bending vibrations. Bands between 295 and $462 \mathrm{~cm}^{-1}$ are interpreted as metal-oxygen stretching vibrations. The broad bands below $295 \mathrm{~cm}^{-1}$ are interpreted as translational lattice vibrations. The Raman spectra of natropalermoite and palermoite are virtually indistinguishable (Fig. 7).

\section{Acknowledgements}

The authors thank Ken Dominick of the Lunar and Planetary Laboratory, University of Arizona, for help with the electron microprobe analyses. Marcelo Andrade of the University of São helped with formatting and provided helpful comments on the manuscript. 


\section{References}

Cameron, E.N., Larrabee, D.M., McNair, A.H., Page, J.J., Stewart, G.W. and Shainin, V.E. (1954) Pegmatite investigations, 1942-45, New England. United States Geological Survey Professional Paper, 225.

Downs, R.T., Bartelmehs, K.L., Gibbs, G.V. and Boisen, M.B., Jr. (1993) Interactive software for calculating and displaying $\mathrm{X}$-ray or neutron powder diffractometer patterns of crystalline materials. American Mineralogist, 78, 1104-1107.

Kampf, A.R., Falster, A.U., Simmons, W.B., Whitmore, R.B. (2013) Nizamoffite, $\mathrm{Mn}^{2+} \mathrm{Zn}_{2}\left(\mathrm{PO}_{4}\right)_{2}\left(\mathrm{H}_{2} \mathrm{O}\right)_{4}$, the $\mathrm{Mn}$ analogue of hopeite from the Palermo No. 1 pegmatite, North Groton, New Hampshire. American Mineralogist, 98, 1893-1898.

Moore, P.B. and Araki, T. (1975) Palermoite, $\mathrm{SrLi}_{2}\left[\mathrm{Al}_{4}(\mathrm{OH})_{4}\left(\mathrm{PO}_{4}\right)_{4}\right]$ : its atomic arrangement and relationship to carminite, $\mathrm{Pb}_{2}\left[\mathrm{Fe}_{4}(\mathrm{OH})_{4}\left(\mathrm{AsO}_{4}\right)_{4}\right]$. American Mineralogist, 60, 460-465.

Page, J.J. and Larrabee, D.M. (1962) Beryl resources of New Hampshire. United States Geological Survey Professional Paper, 353.

Segeler, C.G., Ulrich, W., Kampf, A.R. and Whitmore, R. W. (1981) Phosphate minerals of the Palermo No. 1 pegmatite. Rocks and Minerals, 56, 197-214.

Sheldrick, G.M. (2008) A short history of SHELX. Acta Crystallographica, A64, 112-122. 